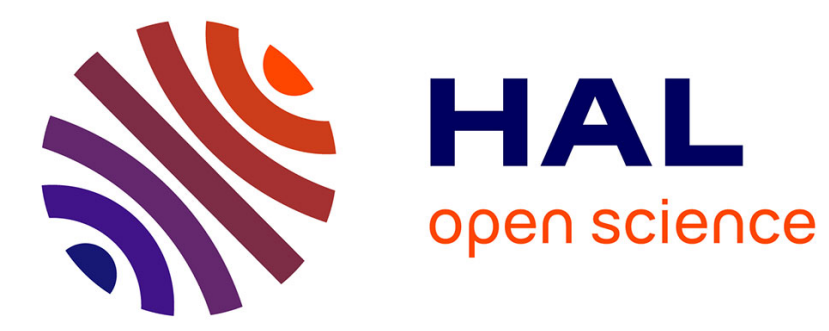

\title{
From CoCom to Dot-Com: Technological Determinisms in Computing Blockades, 1949 to 1994
}

Christopher Leslie

\section{To cite this version:}

Christopher Leslie. From CoCom to Dot-Com: Technological Determinisms in Computing Blockades, 1949 to 1994. IFIP International Conference on the History of Computing (HC), Sep 2018, Poznan, Poland. pp.196-225, 10.1007/978-3-030-29160-0_11 . hal-02386549

\section{HAL Id: hal-02386549 \\ https://hal.inria.fr/hal-02386549}

Submitted on 29 Nov 2019

HAL is a multi-disciplinary open access archive for the deposit and dissemination of scientific research documents, whether they are published or not. The documents may come from teaching and research institutions in France or abroad, or from public or private research centers.
L'archive ouverte pluridisciplinaire HAL, est destinée au dépôt et à la diffusion de documents scientifiques de niveau recherche, publiés ou non, émanant des établissements d'enseignement et de recherche français ou étrangers, des laboratoires publics ou privés.

\section{(c)(1)}

Distributed under a Creative Commons Attribution| 4.0 International License 


\title{
From CoCom to Dot-Com: Technological Determinisms in Computing Blockades, 1949 to 1994
}

\author{
Christopher Leslie ${ }^{1}$ \\ ${ }^{1}$ South China University of Technology, Guangzhou, China \\ chrisleslienyc@hotmail.com
}

\begin{abstract}
The well-known restrictions of exports of computing equipment to the USSR and its allies at the end of the cold war had a curious history. Although the legacy of CoCom is that it seems natural to restrict technology from potential belligerents, it is difficult to determine the policy's efficacy. Started as a corollary to the plan to rebuild Europe after World War II, CoCom originally had nothing to do with computers. High-profile failures brought the usefulness of the economic blockade into question at the same time a new academic definition of technology became popular: technology is not just a material device, but it is also a means of getting something done. Computers were at the center of the quandary: does a device provide an inevitable strategic advantage, or is it the innovation culture that surrounds the device what needs protection? What is more, protecting the institutionalized knowledge from antagonists would require reducing the openness of the academic and scientific institutions that had provided innovation in the first place. When the personal computing revolution was underway, the computing embargo was at the forefront of CoCom, even though PCs had not been prominent at its inception. With the fall of the Berlin Wall and the dissolution of the USSR, it might seem as if CoCom had been successful, yet contemporary critics and practitioners think otherwise. The determinism that underwrote CoCom then operated in reverse: policies granting access to computing networks were imagined to inevitably bring about cultural and political changes. The failure of CoCom to achieve a meaningful hindrance to technology and the unintended consequences of its implementation failed to make an impact in the political arena, but the lessons about technology transfer grained from the evaluation of the embargo deserve greater attention to guide policy today.
\end{abstract}

Keywords: $\mathrm{CoCom} \bullet \mathrm{Comecon} \bullet \mathrm{CMEA} \bullet$ Chincom $\bullet$ technology transfer $\bullet$ policy $\bullet$ determinism

\section{$1 \quad$ Introduction}

In the past two years, high-profile cases involving transfer of U.S. technology to adversarial countries were in the news. In 2018, the investigation of the Chinese company ZTE for selling phones with U.S. components to consumers in North Korea was one of the most visible episodes. An ex-employee of Apple apprehended on the way to China with sensitive corporate information was another. In 2019, Huawei's prominence in trade negotiations seemed puzzling. Although corporate espionage is nothing new, one might reasonably wonder how it became a concern for international politics. Today, 
though, almost seventy years of public policy make it seem natural that international relations should be leveraged to provide technological advances to allies and block or forestall technology transfer to other countries.

The cold war blockade is referred to as CoCom because of the name of the committee established by participating countries, the Multilateral Coordinating Committee for Export Controls. It is sometimes deemed to have been a success due to the lower development status of communist countries after the dissolution of the USSR in 1991. However, at the time there was sufficient evidence that demonstrated the impact of the blockade on technology development was limited at best. Nevertheless, the belief that CoCom helped win the cold war makes it harder to see a different point of view: differences in innovation cultures, economic systems, and ideologies were the hindrances to technological advance in the East Bloc.

In spite of the belief that CoCom was successful, its origins were in post-World War II economic recovery policy, a policy concerned manufacturing equipment and raw materials that had nothing to do with information technology. In headquarters connected to the U.S. embassy in Paris, CoCom started with seven founding nations and came to have seventeen members, mostly overlapping with NATO (without Iceland but including Japan and Australia) [1]. Regardless of the overlap, no treaty ever defined CoCom. Members acceded to the decisions made by the committee only to the extent that national laws could be brought into accord. CoCom monitored the transfer of products to the East Bloc and other countries antagonistic to the alliance for forty-five years, obligating exporters to obtain licenses for a list of restricted products. Disbanded in 1994, the organization solidified the determinist notion that technology provides an inevitable and uniform effect on society.

Placing CoCom into the context of the history of computing serves to underscore how the policy was not the reason for the lack of technological development in the East Bloc. At the same time, this context helps underscore the opportunity cost from caused by the moratorium on collaboration in the scientific and technology community. While it is possible for some scholars to consider CoCom a success because of the strong message it sent, from the perspective of technology policy to support innovation, CoCom was a failure and a dangerous precedent. Through the history of computing, one can see how CoCom had a greater cost than seen in political circles and why technology blockades in fact threaten the innovative community they purport to protect.

\subsection{International Relations Frameworks}

Gauging the effectiveness of CoCom in a political context is trickier than it might seem. Even if the blockade did not limit technological development in the East Bloc, some might deem the policy a success in other ways. The debate between two dominant strands of international relations theory, constructivism and structural realism, can be seen in the debate over whether CoCom was effective.

In international relations scholarship, a constructivist position is one that suggests that security imperatives like CoCom are intentionally exaggerated positions based on ideological constraints. Once the Cold War was established, a scholar like Wendt [2] says, their identities as antagonists shaped their further actions and reconstituted the 
Cold War at each juncture. It was not until the 1980s, Wendt says, that the Soviet Union recognized the wastefulness of this "shared belief" and sought a different self-expression, bringing an end to the Cold War (p. 76). The theory that the west's economic blockade caused deprivation and brought about the Wende does not explain the timing of this choice nor the other times the USSR had instead intensified its position. Wendt reminds us that culture shapes our expectations of events. If I am driving a car in a culture where a red light means go, I will fail to anticipate the actions of other drivers when we come to a traffic light and get into an accident - and I may begin to question the efficacy of traffic lights. Once we are all in agreement, though, we will act in ways that reinforce the system. He applies this to the Cold War:

Once the cultural formation known as the "Cold War"' was in place, the U.S. and Soviets had a shared belief that they were enemies which helped constitute their identities and interests in any given situation, which they in turn acted upon in ways that confirmed to the Other that they were a threat, reproducing the Cold War. In each case socially shared knowledge plays a key role in making interaction relatively predictable over time, generating homeostatic tendencies that stabilize social order. (p. 187)

As a result, one might say that the U.S. and Soviet militaries had a "common interest" in continuing the cold war (p. 275). Changing policy and learning to cooperate, Wendt says, means that states must rethink their own identities as much as they must win against their adversaries. A constructivist point of view then can see a policy like CoCom as something that created not only a sense of the USSR as a communist opponent but also embodied an identity for the capitalist west. This construct was dependent upon a vision of technology as an independent, nationalistic actor that is not in accord with the history of technology.

This constructivist view, which Wendt articulated at the end of the cold war, was a response to structural realism. In this school of thinking, one assumes that in the international realm, nations act only according to their own self-interest because there is no authority figure. Starting from this point of view, it is best to take threats seriously. Baldwin [3], for instance, states that the economic blockade functioned better as a "symbolic moral condemnation of communism" than an effective drag on the Soviet economic system, which "had little chance of success." Although symbolic, it is not as if the policy had no consequences; the U.S. needed to convince the rest of the world that communism was a threat, which it could not do if it were engaged in friendly trade relations with its purported enemy (p. 241). For this reason, Baldwin says the symbolic nature of embargo has been underappreciated. Even if the blockade fell short of achieving its stated goals, a structural realist could say that it was successful because it helped the U.S. to effectively communicate its intentions and positions. Certainly, Baldwin notes, the USSR did not increase its territory while the embargo was in place and one cannot prove that the USSR's economic growth would have been different had there been no embargo. Looking back on the legacy of these debates, scholars like Blackwill and Harris [4] have recently suggested that the blockade became a way for the U.S. to express its moral superiority over the communist system, even if within the first ten years of its life the blockade did not seem to be accomplishing its stated aims.

The realist position makes the evaluating the blockade troublesome. A structural realist position would say that the blockade was successful even if it did not hamper the 
development of technology in the East Bloc. The policy allowed the U.S. and its allies to communicate its pleasure of displeasure in events in a way less costly than war [3]. Technology blockades remain popular after CoCom, but their effectiveness is in the context of structural realism. In this context, the well-documented ability to circumvent the barrier, the reluctance of practitioners before and after 1991 to credit the embargo for the lack of innovation, and the lost economic opportunity do not mean the blockade was a failure. These costs, in fact, help to make the blockade a more effective symbol.

That the East Bloc failed to match the success of the capitalist west in innovation, particularly in the realm of computers, can combine with the assessment from those who hold a structural realist position to provide legitimacy for implementing controls like CoCom in the future. However, one could just as easily point to internal factors that dampened the development of technology. ${ }^{1}$ What is more, the realist position fails to account for the international character of scientific and technical innovation. The cold war frame constructed by CoCom was of an insular, innovative nation that bestows the benefits of its progress only an elite group of allies - which is counter to the essential characteristics of international collaboration that foster innovation.

\subsection{Science and Technology Studies Frameworks}

A context provided by science and technology studies (STS) supports the notion that this policy would fail to meet its overt goal of hindering technological development in the East Bloc. The design of CoCom relied on the notion of technological determinism, what STS scholars label as a fallacy, presuming that technological devices are innovated in isolation from historical, cultural, or ideological constraints. As a result, determinism leads to the conclusion that a technological device can be easily uprooted and used in other circumstances with divergent histories, cultures, or ideologies, impacting the recipient in an unequivocal and uniform way. A device that gives a strategic advantage to the United States or England can, according to the determinism of CoCom, be easily used in different circumstances.

The determinism implicit in CoCom can be seen in STS studies contemporary with its creation. One notorious example is Wittfogel's 1957 Oriental Despotism [5]. In this study, Wittfogel attempts to explain why China's early technical superiority did not lead to a free society. He suggests that the achievement was actually China's downfall: the organization of labor needed to produce large scale irrigation in the pre-modern period led to despotic forms of government. What he calls the "hydraulic state" makes it difficult for contemporary China to embrace the wider swath of authorities needed to "counterbalance and control the political machine" (p. 49). Wittfogel's suggestion that technologies require specific forms of organization that lead inevitably toward only one cultural outcome reflects the same kind of deterministic attitude toward the interaction between technology and society that supported the CoCom embargo.

As the cold war waned on, though, scholars would shy away from inevitable causeand-effect interpretations. Mumford [6], for instance, suggested in 1964 that the west's

1 See Kitova and Kitov's assertion that it was the unwillingness of the Party leaders in the USSR to accommodate new thinkers in "Anatoloy Kitov and Victor Glushkov," this volume. 
lust for nuclear weapons, rockets, and computers puts it in danger of succumbing to totalitarian ideals of the "pyramid builders." Whereas Wittfogel claimed technologies produce inevitable cultural outcomes, Mumford wrote about the danger of totalitarian ideologies in the way that technology was used. That same year, Ellul [7] wrote that technology was not so much as a device but the constellation of methods and techniques used in many human endeavors. In the following years, STS scholars would effect a more nuanced description of the interaction between technology and society. Winner [8] in 1977 proposed a terminology shift: what most people call technologies are really apparatus, so he proposes that we instead study technique, a word he notes comes from

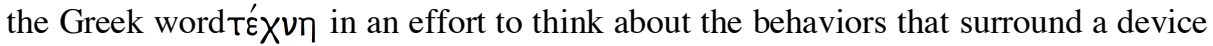
and make that device a part of a coherent cultural system.

This developing understanding of technology to a certain extent lessened the concern that the East Bloc would obtain capitalist devices because their ill fit with economic systems and management styles behind the iron curtain would render them less effective. At the same time the formulations of Ellul, Mumford, and Winner blossomed into the modern field of STS, questions about the efficacy of CoCom caused new implementations of the technological blockade, particularly in 1979. In 1990, historian Pacey [9] would coin the phrase "technological dialogue" to describe the innovation that occurs when devices are passed between cultures and adapted to fit new circumstances. Additionally, Pacey points out an unintended opportunity cost of isolation: lost potential innovation. Throughout the history of technology, Pacey shows how the effort to transfer technology from one set of cultural, political, or economic circumstances to another sparks innovation. One example he provides is the printing press, which he describes as the result of interaction among cultural groups. Paper and movable type were invented in the east, but writing in Europe was made on vellum. Writing on calf skin required sharper implements that would destroy Chinese paper, Pacey notes, so when paper was brought to the West, it needed to be strengthened. This more durable paper then supported the development of printing with metal type. As an alternative to the supremacy of one nation's technical system over the other, Pacey's concept of technological dialogue shows how key innovations derived from the community of nations.

This transformation of STS theory neatly follows the development of CoCom. The goal of isolating the East Bloc from materiel that could (uniformly and unequivocally) provide a tactical advantage transformed into a concern for exposing the bloc's engineers and scientists to the organizations and methods for developing technology. Even as the scholarly work in STS and economics came to suggest that withholding devices and threatening international exchange would not accomplish policy aims, the determinism that lies behind a technological blockade remained politically compelling. The reliance on this policy had negative effects. As will be seen below, the embargo led to economic loss and strained diplomatic relations. Mofre importantly, an effective policy to stop transfer of knowledge and experience would have had to be effected in universities, which were loath to sacrifice academic freedom not just because it was a cherished principle but also because of their assumption that a robust international exchange of ideas best fostered innovation. The history of computing technology offers an excellent window onto these debates and transformations because during this period compu- 
ting devices were, at the time CoCom was first organized, thought of as business machinery, and thus exempt from the blockade, then later increasingly as devices with military applications that should be withheld from the East Bloc and finally as agents of information exchange that could serve as a framework for innovation.

Accordingly, this paper takes up the various iterations of CoCom with an aim of rethinking the received wisdom of these policies. It starts with a history of the iterations of CoCom and the related Comecon and Chincom organizations, providing relevant examples from the history of computing to make the argument that the overt economic goals were not served by the economic embargo. In the subsequent iterations of the policy, it becomes clearer that the technological blockade counters the aims it purports to accomplish.

\section{Establishment of the Economic Blockade Concept}

CoCom was established in 1949 in The Hague by members of the Atlantic Alliance who agreed to limit exports to the Soviet Union and its allies. Thus, the policy that would be so influential in the diffusion of computers was developed when electronic, programmable computers were in their nascent stages of development.

The notion of an economic blockade had been tested in other contexts. The U.S. 1917 Trading with the Enemy Act and the 1946 Atomic Energy Control Act were important antecedents to the idea that supplies and information should not be given to belligerents [10]. A U.S. report after World War II noted that U.S. technological devices had "significantly assisted" the Japanese air force, and a growing fear was that the same could happen with the Soviet Union [11, p. 131]. In 1948 and 1949, an economic embargo was enforced by a licensing system for goods headed to Europe out of pretext that material was in short supply for U.S. domestic needs. The policy that would come to be well-known for its involvement in hindering the diffusion of computing had little to do with technology at all.

\subsection{Enforcing U.S. Policy beyond Its Borders}

Export controls came to be enforced outside the U.S. as a corollary to the Marshall Plan to provide US\$12 billion in aid to sixteen European countries to rebuild after the war. When Secretary of State George C. Marshall described his plan to assist European rebuilding at a 5 June 1947 commencement address, he did not mention the embargo. According to Libbey [12], though, in addition to restarting the European economy, a "less public" rationale was to contain communism (p. 137-8). A preliminary meeting in Paris at the end of the month between the U.S., Britain, France, and the USSR demonstrated the awareness of this goal. Soviet Foreign Minister V. M. Molotov declared his opposition on July 2, claiming that the plan would divide Europe and subordinate smaller countries. Thus, before the Marshall plan was codified, there was a recognition that the aid was not entirely altruism.

After Molotov walked out of the meeting, the USSR announced a conference to plan an alternative path to recovery. The USSR would propose facilitating trade among its 
allies with centrally planned economies through the Council for Mutual Economic Assistance (CMEA, sometimes referred to as Comecon) with Bulgaria, Czechoslovakia, Hungary, Poland, and Romania. As a practical matter, this would mean the USSR and member countries would not be eligible for U.S. financial assistance. This decision "proved painful" for Czechoslovakia and Poland, which had planned to receive U.S. aid $[12$, p. 135, 138]. The sides were set for a trade war.

Policy makers in the U.S. considered the Soviet rejection of aid to be a "threat to world peace" that justified export controls [13, p. 130]. The same month Molotov walked out, the U.S. Congress passed the first export licensing requirements. Three tiers of exports were delineated. War materiel was embargoed unconditionally, while anything that could enhance war potential and bolster the Soviet economy was subject to limits in quantity (lead, copper, zinc; trucks, steel rails, freight cars) [14]. Businesses seeking to export metals, fuels, and foods - categories that amounted to about twenty percent of U.S. exports - were to obtain prior licenses in an effort to prevent domestic scarcity [12, p. 144]. Although this policy was ostensibly not aimed at the USSR, context makes the intent clear.

Prompted by the Czech coup and the Berlin blockade, the U.S. in March 1948 expanded the embargo to include all goods headed to Europe in anticipation of disbursing Marshall Plan aid. The U.S. Department of Commerce drafted lists of prohibited articles [11]. The embargo lists were completed by August 1948 while the Berlin airlift was well underway. From their offices in Paris, the Economic Co-operation Administration demanded compliance with the lists as a condition of the first year of Marshall Plan funding. Thus, the implicit intention of this policy was revealed to be "political considerations rather than economic necessity" [12, p. 145] and aid was formulated in part as pressure to regulate trade of strategic goods with the Soviet bloc [15, p. 23]. The blockade led to a retaliatory Soviet ban on exports of manganese and platinum to the U.S., metals needed for communication equipment and munitions, at the end of 1948. It was in this context that the U.S. Congress passed the Export Control Act in February 1949 , a stringent embargo that included the licensing policy. It would govern trade policy for twenty years.

The first meeting of CoCom in November 1949 came at the end of a tense year. The Berlin airlift had ended in late spring 1949, but in the fall, dreams of unifying the Germanies faded when the Federal Republic of Germany and the German Democratic Republic (GDR) were established. Events in the Chinese civil war also came to a head: Mao Zedong proclaimed the communist People's Republic of China in October, the nationalist opponents fleeing to the island of Taiwan. The early Soviet explosion of an atomic bomb on 29 August 1949, years ahead of U.S. intelligence predictions, was blamed on illicit access to this research. The idea of an economic blockade fit into a larger policy of containment.

The formation of CoCom - a consultative group with at first seven members (see Table 1) - was a diplomatic success on the part of the U.S., but it came with dissensus $[13$, p. 139]. It would have an immediate economic impact: U.S. exports to the Soviet Union, which had been $\$ 236$ million in 1946, dropped to \$2 million in 1953 [16]. The U.S. made many demands on their European allies from 1948 to 1952, but these were accepted because of the prospect of Marshall plan aid. Adler-Karlsson [15] reports that 
one official said, "Western Europe sold out their trade principles for good American cash." The uncertain duration of funding led to an effort to accede to U.S. policy while simultaneously sustaining trade (p. 47). As Marshall Plan aid was coming to an end, though, the U.S. Mutual Defense Assistance Act of 1951 (also known as the Battle Act) stipulated that no military, economic, or financial assistance would go to any country unless it embargoed nations that threatened the security of the U.S. The blockade was never negotiated as part of a formal treaty and relied on voluntary, multilateral cooperation. From this point forward, though, it would be enforced by the threat of the loss of U.S. economic assistance.

1949 Founders: Belgium, France, UK, Italy, Luxembourg, Netherlands, U.S.

1950 First Expansion: Canada, Denmark, Norway, Portugal, FDR (West Germany)

\begin{tabular}{ll}
\hline 1952 & Japan \\
\hline 1953 & Greece and Turkey (after admission to NATO) \\
\hline 1985 & Spain \\
\hline 1989 & Australia
\end{tabular}

Table 1. Members of CoCom. Significant suppliers of technology, such as Sweden, Switzerland, South Korea, and Taiwan, never became part of CoCom. The CoCom export lists were always secret, but one can say that in the mid-1980s the embargoed countries included much more than the East Bloc: Afghanistan, Albania, Bulgaria, Cambodia, Czechoslovakia, Cuba, the German Democratic Republic, Hungary, Laos, Mongolia, North Korea, the People's Republic of China, Poland, Romania, the Soviet Union, and Vietnam [1]. Thus, compliance with CoCom restricted a great deal of trade with potential partners.

\subsection{CoCom Expansion and Chincom}

China and Japan came under the purview of CoCom in the aftermath of the Korean War. North Korea invaded South Korea in June 1950. North Korea had sided with China's communist party in its civil war, so China reciprocated, as did eventually the USSR. The war drew to a stalemate by 1951. In 1952, when Japan regained its sovereignty, Japan expressed its desire to join CoCom. Concurrently, China declared that the United States was an adversary. In addition, in April 1952 USSR launched a "Peace Offensive," inviting almost 500 people from 47 countries (including the United States) for an economic conference. These events prompted a CoCom meeting on 26 June 1952 to discuss Japan and China. The end of Korean War and Marshall Plan funding in 1953 prompted a recession in Europe, and European leaders requested an easing of export restrictions. The U.S. acquiesced, reducing the list to 200 items.

The U.S. opposed Britain, France, and Canada in admitting Japan. First, it did not want to weaken NATO, which was mostly synonymous with CoCom. Second, the U.S. wanted stricter treatment of trade in Asia, particularly on China. For its part, England wished to constrain Japan in order to control competition [17]. China was a more difficult question: would an embargo have the unintended consequence of strengthening China's ties with the USSR? Or would an alliance create an economic burden for the 
USSR? President Eisenhower sought an evolution of policy - the blockade should become "economic, political, and psychological" and not just a military standoff. In this, he was joined by Churchill, who believed that trade was "a weapon to penetrate the iron curtain" [17, pp. 28-29]. The compromise was that a group subordinate to CoCom, Chincom, was established. For a brief time, the committee sought stricter foreign trade barriers on China than had been in place for the East Bloc, a policy that resulted in what came to be known as the "China differential." CoCom hoped to use Japan as a "wedge" between the USSR and China [17, pp. 25-26]. The China differential foreshadowed a larger shift in policy because it was not a strategic effort, but instead targeted to influence political development $[15$, p. 204]. Japan would join CoCom in 1952, and the China differential was ended in 1957. The blockade had become ideological, but still it did not address computing.

\subsection{Computing in the Early Years of CoCom}

CoCom did not originally apply to computers. In the 1950s, the idea of a computer transformed from a mathematical device to a data-processing machine for business [18, p. 105]. In 1952, a "a spectacular publicity stunt" was arranged for ENIAC, one of the first commercial computers: it was used to predict the U.S. presidential election result using voting returns in key states [18, p. 110]. At the end of the 1950s, journalists would refer to the computer industry led by IBM and the "seven dwarfs," or companies that were attempting to enter the market (p. 117). Consequently, when CoCom was established in 1949, there was still little attention paid to computing devices.

Although computers were not part of the CoCom deliberations, technological devices were. The USSR in 1955 exploded its first hydrogen bomb and launched the Sputnik satellites at the end of 1957, the latter being a particular embarrassment especially because the U.S. space program had been beset by failures. The feedback from U.S. diplomatic posts was that this launch had caused a crisis of confidence in the ability of the capitalist approach to high-tech development. What it also showed, though, was that economic containment was not blunting Soviet technology. European leaders took these developments as a sign that the blockade was not reaching its aims, but the U.S. shifted its rationale to state that the embargo should continue "on moral and symbolic grounds" [4]. In the wake of Sputnik, the U.S. made efforts to connect the scientific community between east and west. In 1958, some results of U.S. nuclear research were published. The following year, an agreement was reached for academic visits by scientists and joint symposia [19, pp. 100-101]. CoCom countries requested and the U.S. granted a reduction of the proscribed lists in 1958. The new list of 100 items was mostly related to "a narrow band of military equipment" [12, p. 148], even though the United States continued to enforce its own embargo of a larger list of 700 items to the USSR.

As computing developed near the end of the 1950s, the U.S. estimated it was four years ahead of the Soviet Union and considered an embargo necessary to maintain that edge. The British, however, felt that computers were business machines and were exempt. From 1960 to 1961, the United States sought to convince the British that the majority of computing equipment in the USSR was used for military purposes [11, p. 137]. China, with the assistance of the USSR, had begun its own computer research 
program and in 1964 exploded its first nuclear bomb. In 1965, China sought to import British computers, the Electric-Leo-Marconi KDF-9, and others. The U.S. again sought to tighten restrictions at this time, and in 1966 even suggested the return of a China differential for computers [11, p. 141]. The USSR also made progress in computing in the 1950 s, creating a stored program digital machine, producing small computers serially, conducting a high-level programming seminar, and building one of the first "supercomputers." These developments were contemporary with U.S. and UK achievements but independent and innovative [20]. Even if CoCom countries had a technological edge in computing, it did not seem as if it would last.

\section{Relaxation of CoCom with a New Definition of Technology}

After its first twenty years, CoCom went through a period of reevaluation and relaxation. The interconnectedness of world markets made it increasingly unlikely that a small group of nations could effectively control the flow of devices, resulting in a turn to technical knowledge, and the economic losses and political strife caused by the blockade could not be defended with a growing awareness that technologies are imbricated in cultural assumptions that are not easily changed. Two revisions of the U.S. laws that governed exports in 1969 and 1979 reflect a shift in the academic understanding of the relationship between technology and society. Computers were finally added to the law in 1979 , creating challenges in the academic realm that would undermine the policy further.

\subsection{The Politics of Technologies}

In the 1960s, U.S. government funding was provided for distributed computer networks. Notably, Paul Baran went against the spirit of the technology blockade, insisting on publication of his research on communication networks that would survive a nuclear attack. His thinking was that the evidence that the U.S. military could survive a first strike would deter a Soviet attack. Instead of trying to make it available to spies, he says:

We published it! I gave a course on it at the University of Michigan in '65. We were a hell of a lot better off if the Soviets had a better command and control system. Their command and control system was even worse than ours. [21]

Although Baran's communication network was never built, his attitude toward openness would be reflected in the leadership of ARPANet.

A U.S. Central Intelligence Agency (CIA) report in 1961 underscored the point that a blockade would be ineffective. Even an effective blockade would have "no impact" on Soviet military preparedness. Only Soviet consumers would feel the pressure [14, p. 127]. Multilateral cooperation for such a blockade would be unlikely, though, so the CIA said unilateral embargo would be "an exercise in futility" [14, p. 128]. As an alternative, the CIA determined that targeted restrictions might be effective in the short 
term. For instance, the USSR had made a strategic decision to expand its energy production, not only for its own interests but also so that it could generate cash purchase Western technology [4] As a result, the CIA recommended withholding large-diameter pipe in 1962-1963, resisting the USSR's westward expansion of the Druzhba oil pipeline. A Soviet pipeline, the U.S. believed, would provide immediate financial gain as well as future political power.

The U.S. stance on the pipeline project would show, however, how an economic blockade has unintended political consequences that reach beyond the opportunity cost of lost trading partners. President John F. Kennedy witnessed this during the Cuban missile crisis of October 1962. "How strong would allied support for the U.S. be in a future confrontation with the U.S.S.R. when the latter might threaten to turn off the spigot of oil?" [12, pp. 149-150]. The U.S. denied the pipe needed for the project, but the Europe saw trade opportunities. The U.S. bypassed CoCom and went instead to NATO, winning a 25 November 1962 recommendation that NATO members withhold the pipe. This was only a temporary victory; NATO was advised to reverse this decision because West Germany and Britain already had contracts for the oil. The pipeline began operation in 1964. As noted by Mastanduno [14], the U.S. got its way but it at a high cost and the pipeline was completed anyway; furthermore, allies became suspicious that U.S. had a vested interest to protect its own oil industry instead of following a symbolic policy of containment, further undermining support for the blockade.

With the 1969 moon landing having assuaged the sense of inadequacy caused by Sputnik, the U.S. decided it was time to engage further with the East Bloc. Given the general mood that embargoes would be less successful than engagement, a relaxation of CoCom took place in the ten years after the moon landing. The Export Administration Act of 1969, which dictated how the U.S. would conform to CoCom, was passed to loosen the restrictive character of the expiring 1949 and 1951 acts. The U.S. Congress sought to promote East-West trade, aware that "trying to control Soviet economic growth was now untenable" and in the end only disadvantaged U.S businesses [4]. Aware of the East Bloc's desire for high tech equipment in computers and milling, the act encouraged trade with all nations with the intent to obtain "tacit Soviet agreement to abide by the status quo in international affairs" [19, p. 101]. The new legislation sought to maintain a technological differentiation between capitalist and communist countries, but it also acknowledged that trade should not be sacrificed for national security. This assuaged U.S. businesses, who believed they were being kept out of East Bloc markets by the U.S.'s regulations, which were stricter than in other CoCom countries [22]. After its first twenty years, CoCom's economic embargo had been redefined as a strategic embargo

\subsection{Reevaluating the Threat Posed by Equipment}

In spite of the embargo, it became clear that the USSR could obtain sensitive equipment illicitly. "The incentives for firms to bypass CoCom's formal controls were great" [14, p. 181]. Often cited is a 1972 instance where the Soviets obtained precision ball bearing equipment from the Bryant Grinder Corporation in Vermont that would help them make guidance systems for nuclear missiles; Soviets conducted MIRV tests the next year, 
leading some analysts to state that the grinders alleviated a "critical bottleneck" [14, p. 172]. This export of 168 grinders to make anti-friction ball bearings for use in gyroscopes was justified because the equipment was also available from Japan, Switzerland, Italy, and France, not to mention that other equipment of this type had already been sold [14, 16, 23]. In 1979, the U.S. semiconductor I. I. Industries was convicted of trade violations after they mislabeled semiconductor equipment in order to facilitate its sale to the USSR in 1975 and 1976. The processing equipment was sent first to Canada, then to Switzerland, and ultimately to the USSR to hide the circumvention [16]. These were serious breaches, but a growing question was whether they provided an advantage.

The new thinking in academic definitions of technology in the 1960s was mirrored by evidence on the ground that devices, whether obtained legally or illicitly, might not positively impact a country's military advantage. The Soviet innovation in computing seen in the 1950s seemed to have stalled by the late 1960s, even though the interest in computing increased. ${ }^{2}$ This resulted in a shift toward acquiring capitalist technology.

As noted by Goodman [20], obtaining computing devices was an unsuccessful transfer of technology not only due to CoCom but also because of what might be called cultural differences. Potential partners were unwilling to come to the USSR because the country did not have the money, expertise, or "positive working environment" to get companies or individuals to stay for years. In addition, Goodman states, the Soviets constrained technology transfer themselves through travel restrictions, subject matter prohibitions, centralized meetings control, and small-volume purchases. It was not the embargo so much as it was local policy that impeded development. ${ }^{3}$

The blockade was far from impervious. Beyond the direct purchase of computing technology, the USSR attempted other methods of technology transfer such as "sister plant" relationships with IBM, turnkey production facilities, licenses and joint projects, not to mention encouraging the defection of trained personnel. Weaker measures of technology transfer such as academic exchanges, plant visits, training, and conferences were also tried. However, these were not as effective as they could have been. Often the Soviets lessen the potential by "interposing" intermediaries [20, p. 123] like the KGB or foreign trade organizations, limiting feedback between the suppliers and receivers. These might allow information to pass between the nations, but they would not result in the advantages gained by their counterparts on the other side of the iron curtain who worked in different environments. Even when equipment was obtained by the USSR, it would not have an impact overall. Peters [24] calls 1 October 1970, the day when the Politburo reviewed a proposal for Soviet decentralized network for economic planning, "the day of reckoning," and notes that nothing was built in the years that followed (p. 161). The cultural differences were much more effective in limiting development.

The strength of the cultural barrier calls into question the high diplomatic cost to the U.S. of enforcing the technology embargo. The U.S. probably would have been successful in convincing its allies to join the program voluntarily, Adler-Karlsson [15]

2 For an updated perspective on the supposed lack of innovation, see Kitova and Kitov, "Anatoly Kitov and Victor Glushkov," and Kitov, "Main Teleprocessing Monitors," this volume.

3 For further insight into this difficulty, see Sikora, "Cooperating with Moscow," this volume. 
noted in 1968, but instead the U.S. chose to coerce them with the threat of withholding Marshall Plan aid. Thus, the persuasive value was lost (p. 48). The outcome of the policy did not compensate for the bad feelings that came along with it, Adler-Karlsson continues. Soviet development, measured in terms of gross national product, was at most delayed after ten years of embargo. In terms of military development, the delay was about four months (p. 190-191). Both of these measurements presume there were no counter actions; assuming that to CoCom policy was fifty percent effective, the delay was more like 6 months and 2 months, Adler-Karlsson writes (p. 200). This slight gain was at the cost of lost trade as well as diplomatic conflict, even if one is not convinced that the true barrier was one of technical culture.

In parallel with the growing awareness in STS that devices reflect a constellation of historical, economic, political and ideological considerations, the experience of the 1960 s led to a reform in thinking about the technological embargo. The recognition that the devices themselves were not the main issue is seen in the final report of a U.S. task force headed by the president of Texas Instruments, Fred Bucy. The so-called Bucy report [25] in 1976 called for a change in thinking. Except for military devices, the Bucy report recommended a relaxation of trade barriers. Recognizing that superiority comes from knowledge, the report recommended loosening the restrictions to devices themselves. Accordingly, techniques like cryptography were determined to be a weapon and placed under restricted access by the Arms Export Control Act of 1976.

\subsection{Adding Computers to CoCom}

With a new vision of technology in the West and growing demand in the East, requests for exceptions to CoCom proscriptions increased. In 1966, there were 228, with 12.7 percent (30 exception requests) coming from the U.S. By 1978, there were 1,680, with 62.5 percent (1,050 requests) of these coming from the U.S. [26]. The value of the exceptions in 1967 was $\$ 11$ million, but by 1977 there were $\$ 214$ million in exceptions [16]. As shown in Table 2, in 1971 computer exceptions were 23\%, or $\$ 21$ million; by 1977 their proportion was nearly three times as great and the value had increased eightfold. These exception requests in 1970s show that revision of CoCom was needed because, although a majority of requests involved computers, there was no agreement on what was appropriate.

The recognition that technology was more a way of doing things than it was access to physical devices came at a time when mainframe computers came under its purview. In the 1970s, a shift in sentiment about the embargo was reflected in congressional studies. The end result was a recommendation that the lists of restricted items be shortened and licensing procedures be "less onerous" in order to promote U.S. economic competitiveness [4]. The new Export Administration Act, passed in 1979, described how the U.S. would interpret and implement CoCom. A shift in the Congressional debate was palpable. One contemporary reviewer noted:

Export restrictions employed as a foreign policy tool are rarely effective in influencing the internal or external policies of economically powerful nations like the Soviet Union, 
which is not dependent on U.S. exports, because such use makes it impossible for foreign leaders to change their conduct without damaging their individual or national pride $[27$, p. 91]

The symbolic nature of the embargo came under scrutiny from many angles. Given the recent recession, not to mention the U.S. effort to promote international trade for its business, the costs of the economic embargo were harder to justify. Additionally, the use of the embargo as a foreign policy symbol was questionable; because of their "inflexibility," once established as a symbol they cannot be removed "without sending unintended messages to other nations" [27]. Thus, the U.S. moved from a realist to a constructivist approach in this act.

\begin{tabular}{ccc}
\hline Year & $\begin{array}{c}\text { Value of computer exception } \\
\text { requests (\$ million) }\end{array}$ & $\begin{array}{c}\text { Percentage of computer } \\
\text { exceptions to total }\end{array}$ \\
\hline 1971 & $\$ 21$ & $23 \%$ \\
\hline 1972 & $\$ 66$ & $39 \%$ \\
\hline 1973 & $\$ 80$ & $50 \%$ \\
\hline 1974 & $\$ 120$ & $66 \%$ \\
\hline 1975 & $\$ 147$ & $64 \%$ \\
\hline 1976 & $\$ 123$ & $52 \%$ \\
\hline 1977 & $\$ 168$ & $63 \%$ \\
\hline
\end{tabular}

Table 2. Requests for exemptions from CoCom export restrictions for computing equipment.

In addition to demanding that foreign policy consider the significant economic cost of the embargo, the Act broadened the definition of technology as not just devices but also "information and knowhow." According to the act, training and services were just as important as prototypes and manuals. Henceforth, the knowledge or devices to produce goods, including computer software, would be proscribed. It also put supercomputers under embargo, but it left it up to the Commerce Department to set the definition and access guidelines. Finally, the act authorized the U.S. executive branch to control exports in support of foreign policy and to limit trade with countries who supported terrorism. As much as Chincom had aimed to influence politics, it had been limited to China and was relatively short lived. Now, perhaps because it was clear that the impact of the embargo on devices was minimal, the new law authorized the use of CoCom as a political tool. The Soviet invasion of Afghanistan at the end of the year led the Carter administration to suspend all CoCom licenses to the East Bloc, bringing and end to the relaxing period with respect to the USSR and its allies [28]. This gave the U.S.-led blockade against communism an opportunity to show its sense of moral superiority; it was a system not just "different from or irreconcilable with" the East Bloc, nor was it a policy centered on "self-interest," but simply one that was "morally superior" [4].

The U.S. established diplomatic relations with the People's Republic of China on 1 January 1979 and committed to support efforts to modernize the country. Although the U.S. had been imposing a national embargo against China, within a few months they became a favored trading partner. With respect to China, the new status led to new guidelines, particularly for dual-use technologies, including electronics and computers [29]. This policy had a noticeable effect on technology exchange. Under the new policy, 
China would be allowed to receive exports at twice the level as given to Eastern Europe. In 1983, a new policy to allow exports of seven categories of goods included computers and computerized instruments. As result, exports to China increased eightfold in the ten years after 1979, to $\$ 1.7$ billion, while trade to the USSR and Eastern Europe decreased [29]. In 1981, Burroughs Corp asked for permission to install a B-7830 a computer in 1983 in Beijing for $\$ 5.5$ million. This computer, which could compute 3.5 million instructions per second, would be the most sophisticated computer in China. An earlier computer installed in 1980 for the Chinese census was capable of 1.08 million instructions per second. [30]. These projects would lead to further expansion in the market. In 1985 , IBM donated, at a cost of $\$ 1.7$ million, 100 microcomputers (their 5550 model) to the Chinese Ministry of Education. In 1986, IBM planned to begin the joint manufacture of the 5550 with a Chinese company. Hewlett-Packard also agreed to provide China with one of its minicomputers [31]. China was not unique in these acquisitions, but in terms of CoCom, this new China differential reflects the political weight accorded to technology transfer.

\section{Personal Computing and CoCom}

The personal computer revolution began during the relaxation period. Intel began to sell its 4004 microprocessor, a "computer on a chip," in 1971 [18, p. 236]. The first microprocessor-based home computer was the 1975 Altair. Like other hobbyist products, it was sold as a kit. Apple introduced its first computer the next year. The intention of these designs was to "liberate" computers from their business uses. IBM came around in 1981 with the IBM personal computer. The personal computing revolution, which aimed to bring computing to a wider range of users, brought with it a concern that it could provide tactical superiority to belligerent countries. Even so, there was a growing awareness that access to the devices themselves would not give a country an advantage. This tension is seen in how government used CoCom to justify its actions.

\subsection{Unintentional Impact on Universities}

The redefinition of technology in the 1979 Export Administration Act from device to technique was protested almost immediately by universities, where politicians and bureaucrats assumed soft technology transfer occurred. In February 1981, presidents of Cornell, MIT, Cal Tech, the University of California, and Stanford wrote a letter to the protest an effort to restrict access to the Very High Speed Integrated Circuit program and other actions related to the export and control of technical research. The presidents feared the that would be a situation where:

faculty could not conduct classroom lectures when foreign students were present, engage in the exchange of information with foreign visitors, present papers or participate in discussions at symposia and conferences where foreign nationals were present, employ foreign nationals to work in their laboratories, or publish research findings in the open literature ... Restricting the free flow of information among scientists and engineers would alter fundamentally the system that produced the scientific and technological lead that the government is now trying to protect and leave us with nothing to 
protect in the very near future. The way to protect that lead is to make sure that the country's best talent is encouraged to work in the relevant areas, not to try to build a wall around past discoveries. [19, pp. 137-138]

Rather than classify the research, the presidents requested only that the sensitive parts of the research be carried out in secure facilities. The Corson report [19] would later reinforce the necessity of the open research community for technical and scientific progress.

In a related September 1981 incident, the U.S. State Department official sought to enlist the aid of a professor at the University of Michigan to restrict the access of Qi Yulu, a visiting scholar interested in computer software from the People's Republic of China, from classified information. The official's rationale was "export control and national security concerns," referring vaguely to the Arms Export Control Act and the Export Administration Act. The letter stated that Qi's program of study should focus on classroom activities "with minimal involvement in applied research." Qi should have no access to "the design, construction, or maintenance data" of computers nor "to source codes or their development." Additionally, the officer requested advance notice of "any visits to any industrial or research facilities." The officer concluded, somewhat ludicrously, that in spite of all of this, "Qi should not be denied as full an academic program as possible" [19, pp. 172-175]. This request makes it clear how the principle that technology was a way of doing work was firmly established and how export control policies had assumed a broader scope as a result.

In an exchange, the UM president made it clear that the university cherished its "extensive involvement" with students and scholars from the PRC while also respecting student privacy and the importance of free inquiry as a foundation for technical research. He believed the government's request was unnecessary, because as a matter of policy the university did not conduct classified research, but also noted that "the restrictions you propose can only have a chilling effect upon the academic enterprise." He took a jab at the official, noting that the Reagan administration had promised to reduce government interference, but also questioned whether the that the export control regulations were applicable, calling the laws "lengthy, complex, and ambiguous" and "difficult to interpret even by those dealing daily in munitions or exports." He concluded:

we are insistent that our faculty and our students (regardless of their country of origin) be allowed to operate in their teaching and research functions ... in ways consistent with our academic traditions and the applicable laws, which we believe are totally on the side of openness and do not make it appropriate for faculty to report on or control the activities of our students. [19, p. 181]

The exchange between these two officials was included as part of the Corson report and underpinned the importance of maintaining an atmosphere of free exchange among scientists from different countries on university campuses.

\subsection{Reevaluating Restrictions on Computers}

The USSR's invasion of Afghanistan seemed to be coupled with new communist movements in Angola and Nicaragua. Likewise, after the declaration of martial law in Poland 
in 1981, the administration reinstated oil and gas restrictions [22]. The USSR shot down flight KAL 007 in 1983 after it was mistaken for a spy plane, further precipitating anticommunist sentiments in the United States. The response of the Reagan administration was to revisit the contents of the lists, which had largely been ignored since the $1960 \mathrm{~s}$ [32]. A meeting set in 1982 was politicized by the Soviet military takeover of Poland, leading Reagan to demand an end to sale of technological equipment to the Soviet Union.

At the time of these increased tensions, the ability of the Soviet Union to obtain capitalistic devices was confirmed by a Soviet spy, Vladimir Vetrov, codenamed Farewell. In an editorial printed in several newspapers on 12 January 1982, Secretary of Defense Caspar Weinberger revealed "a massive, systematic effort to get advanced technology from the West" that led to hundreds of embedded Soviet agents who stole many documents, leading to 4,000 Soviet projects based on information gained from this program. The Corson report had pointed out that 70 percent of technology acquired by the USSR had come from intelligence agencies, determining only a few times the loss came from students and universities. The spies were typically visiting researchers who violating their status [33, p. 17]. The conflict between the Corson report call for academic freedom and the Reagan administration's increasingly public attacks on illicit technology transfer show how CoCom had become political theater.

In May 1982, Weinberger decried that the west had been giving the Soviets the technological "rope to hang us," citing the Bryant Grinder Corporation grinders, but said that the Reagan administration would put an end to it [34]. The following year, Weinberger would make the case that all technology transfer and even trade aids the Soviet military. Even when the technology transferr does not have military value, it permits them "to put their own engineers to work on military research and development." When other countries buy Soviet raw materials, they provide "hard currency which the Soviets can use to acquire additional Western technology" [33, p. II-30]. The administration went as far as to accuse CoCom members of selling sophisticated material to the East Bloc [35]. This increasing tension was a prelude to Reagan's call to review the CoCom lists. In a summit in Ottawa in July 1984, the reassessment of the 30-year-old lists led to 58 proposals to expand the list of embargoed goods. "Categories added included computer software, floating dry docks, robots, spacecraft, super alloys, superconductive material, and telecommunications equipment" [12, p. 151].

Energy was again the most prominent among the concerns to the U.S. The Soviets needed 25-megawatt compressor stations and 56-inch pipe that they could not produce for a pipeline project $[14,36]$. The 3,000-mile Trans-Siberian Pipeline to bring natural gas from Siberia to West Germany, France, Italy, Belgium, and Ireland had been funded by German banks in 1981 in exchange for $\$ 10$ billion in trade over twenty years. Even though the project was well underway, the Reagan administration felt it would make Europe dependent on Soviet energy [32]. West Germany was against the sanctions. Aside from the investment in the project, almost 7 percent of West Germany's trade was conducted with countries in the Eastern Europe, and Chancellor Helmut Schmidt did not want sanctions to interfere with his effort to build relationships with East Germany [37]. The U.S., as before, worried about political leverage. The U.S. was successful in gaining stricter control of technology exports, the reason for the meeting, but a 
wider ban on technology exports was not supported. The gas pipeline, notably, would go forward [37]. Two days after the meeting, France sealed an agreement to purchase 8 billion cubic meters of Soviet natural gas a year for 25 years [38]. The friction caused by the U.S. demands again strained allegiances.

To some, it seemed like CoCom restrictions on personal computers were relaxed in summer 1984, a few months after Apple announced its Macintosh computer with great fanfare during Super Bowl XVIII. This was because manufacturers no longer needed exception requests for PCs. After restrictions in the wake of the lists developed to comply with the 1979 act, under pressure from the U.S. computing industry a control limit for smaller computers was set between 7 and 8 million bits per second. Although the U.S. believed that these smaller computers had military uses, it also recognized that U.S. manufacturers were losing ground to European competitors. For mainframes, the limit was raised to 48 million bits per second (it had been 32 million) [39]. For the first time, CoCom sought to protect production or development of computer systems, even proscribing equipment that could manufacture computers that were not restricted. In addition, restrictions on technology with military potential, like distributed databases, CAD, telecom equipment, and switching, were tightened [40].

The Reagan administration's new policies came at an important time for the modern Internet as well. The switch to TCP/IP on the ARPAnet was made official on 1 January 1983 and the DNS system in use today was fully functional by 1985. CSNET (started in 1983, connecting most computer science departments in the US by 1986 as well as connecting many international users) and NSFNET (backbone created in 1985), both of which were funded by the National Science Foundation and used DNS and TCP/IP protocols, ostensibly allowed many users access to high-performance computers. Connecting China or a country from the East Bloc to these networks would seem to be a violation of the demand that access to high-performance computers be restricted. At the end of this period, the Chinese would be connected to CSNET in spite of the presumption that CoCom proscribed the transfer of computer software and connections to high speed computers [41].

\subsection{Increasing the Cultural Argument against CoCom}

More questioning of the cost-benefit ratio of CoCom is evident in the 1980s. Notably, Bertsch [16] writes in 1983, the detente period from 1965-1980 showed limited expansion of imports of western technology but it did not seem to make a big difference in the growth of communism. "The Soviet Union has a poor record of assimilation and diffusion of technology and Western technology will tend to have a short-term impact with fewer long-term implications than in the West" (p. 24). Bertsch counters those who say that Soviet foreign policy was antagonistic in this period to CoCom countries by saying it could have been worse. He asks critics to imagine the USSR had invaded Yugoslavia after the death of Tito, if they had entirely closed access to Berlin, or if they had made a violent response in Poland. These more heinous actions might have transpired had there been no economic interest and ties to maintain, even though either side cannot be proved. Thus, he concludes, there is more benefit to economic engagement. 
This high-handed attitude led Norman Tebbit, the British trade secretary, to warn that the most persistent source of allied tension with the United States was "your claims to be able to impose your laws on people in other countries, inside their own homes and businesses" [42, p. 132]. This was a reaction to a public reminder by IBM to its UK customers that the U.S. government believed it had the right to control the diffusion of technology beyond its borders. Re-exporting technology, they believed, required permission from the U.S. Commerce Department. No one disputed, for instance, that Western chipmaking equipment contributed to Soviet electronics and, in particular, that the designs for the IBM 360 and 370 were used by the Soviets to make their own mainframe computers. The U.S. said it was "unwise" to say that the ability to purchase computers "in a shop on Trafalgar Square or 47th Street, or on the Causeway in Hong Kong" means the item should not be sold to the USSR. Nevertheless, "almost everyone else and certainly all the Europeans believe that now that the personal computer genie is out of the bottle, it is quite impossible to put it back in again" [42, p. 134].

The Corson report in 1982 had noted that the blockade was not the only factor in developing military technology. Even when the Soviet military obtained a device, the absorption of acquired technology was low due to "inhibiting tendencies." There were not incentives for military researchers to innovate, for one. Also, the organizational effort to obtain devices was large and complex, meaning that there were "inefficiencies in transferring information to those who have requested it." Finally, it noted that there were adverse effects from the way the Soviet military compartmentalized its scientists and engineers" [19, p. 19]. In 1985, Goodman [20] continued the made a negative assessment of CoCom, focusing more on the intention of limiting access to technological devices. Goodman seeks to redefine technology as "the know-how to specify, design, build, maintain, and use a product." Technological capability comes not just having a device or information, but what one can do with it.

To illustrate this point, Goodman asks readers to think of the impact of a new journal article on an U.S. industrial or academic researcher. The researcher knows the author and saw a preprint of the article six months before pit was published (thus a year ahead of Soviet a counterpart, where journals arrive six months after publication). The U.S. researcher has a relationship with the author or can easily form one by using the telephone or computer network. Additionally, the U.S. researcher can take more advantage of published research because of on-site hardware and software or the means to get it (p. 125). This context matters when the Soviets obtained a proscribed device. Once acquired, Western hardware would become a "host" for a "Sovietized" prototype (p. 126). However, Goodman points out, copiers were at a disadvantage due to the cultural difference:

Effective development of modern hardware and software is becoming more dependent on comprehensive, sophisticated, integrated, tool environments, which include an interwoven set of computerized tools and a working environment built around those tools. (p. 127, emphasis in original)

As a result, allowing the technology into the USSR was actually more effective than an embargo, Goodman suggests. "Western technology has been a substitute for, rather than a complement to, domestic research and development" (p. 130). This is not to say that 
there was no innovation in the presence of Western devices, just that it was local innovation, like making East Bloc peripherals work with Sovietized copies.

Goodman asks readers to imagine what it is like to be a group of "bright and energetic" scientists who have little experience. Their government is happy with the copy effort because they get a system at an accelerated pace. However, the people who do the work do not enjoy "hacking away" at the good and bad work done by others, and they are not permitted to improve it. Moreover, they are not going to make something new if they then have to maintain it; it is easier to use the American products (p. 131). Goodman counters the Soviet boast of obtaining technology and saving time on development with the long-term detriment to innovation.

To underscore this difference, Goodman notes the difference in the source of innovation. Many industry problems find solutions based on feedback from the user community. The Soviet military is not such a community. Soviet innovators have some privileges above other workers, but their restricted communication does not mirror the user community in the U.S. or Japan (p. 133). The Soviet military is a small group and it is, understandably, risk-adverse and conservative. The U.S. military research community is larger and it is less conservative technologically (i.e., the Soviet military could never have embarked on ARPANet). Even more so, the U.S. civilian community is much bigger than the first two combined, it is robustly diverse, encompassing many types of users and applications, "and is the main prize of what may be the most singular technological competition in history between the U.S. and Japanese computer industries" (p. 133). This community's access to international colleagues for collaboration was key, Goodman says. "No computing community, including that of the US, would be able to move at its current pace if it were to have its contacts with the rest of the world severely restricted" (p. 134). Thus, by 1985, one can see a forceful awareness that the goal of limiting technical development by restricting the flow of technical know-how was seen as severely limited.

Cultural episodes illustrate the growing distrust of CoCom. In 1984, Piet Beertema pretended to announce that the Soviet Union had joined USENET. The April Fool's message, allegedly from General Secretary of the Soviet Union's communist party, read "today, 840401, this is at last the Socialist Union of Soviet Republics joining the Usenet network and saying hallo to everybody" and provided connection details to Kremvax, a fictional computer in the USSR [43]. The so-called Kremvax hoax illustrates the annoyance among CoCom countries with the boundaries to communication with colleagues. The Star Trek film The Voyage Home illustrates this theme to a new conclusion by means of the role played by Pavel Chekov. In the 1966 television series, Chekov was a symbol of the hopes for collaboration in spite of the cold war. Twenty years later, the crew travels back to 1986 and Lt. Chekov, suspected of being a Soviet spy, is injured while being detained. The military does not stop the transfer of technology needed by the Enterprise, is not depicted as stopping the crew from accomplishing its aims, but instead puts a kindly officer in danger. These incidents illustrate the growing awareness that CoCom was a futile exercise that had negative consequences. 


\subsection{Diversions Weaken CoCom Credibility}

Several high-profile failures of the policy underscored how the interconnectedness of trade and a lack of investment in interdiction made CoCom ineffective in battling technology transfer. Soviet agents and businesses interests worked cleverly within the regulatory framework, taking advantage of loose enforcement. These cases demonstrate the difficulty of maintaining CoCom restrictions on computing but also the challenges of seeking enforcement in a globalized production environment.

One way computing devices found their way to the USSR was through subterfuge from foreign agents. In 1983, it was revealed that a Digital Equipment Corporation VAX 11/782 was shipped from New York to South Africa and then to Hamburg, Germany. The next stop of the $\$ 1.5$ million computer, which was also used by the U.S. military, would have been to be Sweden and then to the USSR, but it was seized by West German customs agents [44]. It was revealed that a KGB agent in South Africa had orchestrated the diversion [45].

Some transfer of technology resulted from legal sales. From 1977 to 1980, the Swedish firm DataSaab contracted with the USSR to upgrade the Soviet air traffic control system. The equipment was cleared because it was used for civil aviation. However, it was revealed in 1984 that Soviets obtained military technology in the upgrade - a primary radar digitizer, computerized aircraft tracking, a system programming center, training simulators, and other hardware and software - giving the civilian facility military capabilities. U.S. Commerce Secretary Malcolm Baldridge termed this a serious trade violation. The scandal ended with jail sentences, loss of export rights, and fines [23, p. 120]. This case illustrates the complexity of dual-use technology. ${ }^{4}$

Another scandal involving falsified export licenses entered public notice in 1987. What came to be known as the Toshiba-Kongsberg case is another earnest effort by Soviets to purchase technology legally. The scandal had its roots in 1974, when the Soviets approached the Toshiba Machine Tool Company in Japan but were rejected because of their interpretation CoCom. The Soviets then obtained nine machines from 1976 to 1979 from a French firm. Toshiba became "bitter" because of the lost sale and was more receptive when the USSR returned in 1979 [14, p. 303]. The small Japanese trading house went to a larger house to obtain grinding equipment for large ship propellers. The two arranged a deal with Toshiba Machine Company to sell four roomsized robotic devices. Both would earn a percentage of the five-year, $\$ 33$ million agreement. Kongsberg Vaapenfabrtikk was a Norwegian manufacturer that supplied numerical controller units and software. Toshiba installed four 9-axis milling machines in 1983. More machines were subsequently shipped. The paperwork mislabeled the equipment, calling it a "vertical lathe" that was not on the proscribed export list [23, 46]. The software modification was sent without an export license.

The added symmetry provided by the grinders would make the propellers of Soviet submarines quieter and, as a result, harder to detect. "This was exactly the kind of technology transfer to the Soviet Union that the United States wanted to prevent" [46, p. 267]. Analysts suggested that U.S. might not recover the advantage it formerly held in anti-submarine warfare [23]. These were not items of U.S. origin, but still they violated

${ }^{4}$ See also Schmitt, "Socialist Life," this volume. 
the principles of CoCom. The result was that the Japanese government banned Toshiba from exporting to the East Bloc for one year. The U.S. Commerce department demanded both companies stop shipping sensitive equipment to third countries until it could review their export controls.

In addition to lax enforcement, Toshiba-Kongsberg reveals the difficulty of imposing penalties. The U.S. Congress initially called for a boycott of Toshiba, leaving Kongsberg relatively untouched. Crawford points out why this ban was unsuccessful: by 1983, the U.S. had fallen behind Japan in semiconductors, fiber optics, and robotics, as determined by the Commerce Department. Thus, the U.S. was dependent on trade; 40 percent of advanced electronic components were coming from Japan. Of the 3,000 types of chips needed for the military space program, 93 were coming from foreign companies (all but one of them being Japanese). As a result, about 10 percent of Toshiba's sales were coming from the U.S. Toshiba was supplying about one-half of the world's one-megabyte dynamic RAM chips, and the company had established many corporate alliances with U.S. firms. Had this ban been implemented, it would have imposed hardship on the U.S. The immediate impact would have been billions of lost sales, harming hundreds of companies. Apple computer said it would suffer "financially and competitively" from the ban [46, p. 270]. Not to mention, foreign firms would still have access to these banned products, putting U.S. firms at a disadvantage. Ultimately, the sanctions were weakened.

In the same year as Toshiba-Kongsberg, other cases of subterfuge were revealed. Luxembourg also interrupted a division of the French company Sogexport, Scientific Accessories, that was shipping U.S. equipment for chip etching. The U.S. suppliers seemed to be unaware that Sogexport intended to resell the equipment to the USSR. [47]. Police raided the Tokyo company Prometron Technics Ltd. because of reports they had shipped material to make nuclear reactors to East Germany. The ensuing investigation showed that Prometron had set up business arrangements around the world for Canon and a South Korea firm to ship Japanese-made equipment for advanced chipmaking to East Germany via Hong Kong. The engraving devices could produce about 15,000 chips an hour and "rank among the technologies most closely controlled by western allies." In 1987 and 1988, shipments of equipment worth more than \$10 million were made, but Canon maintained that it was unaware of the ultimate destination [48].

The failure of CoCom to stop the illicit diffusion of computing technology was coupled with a growing awareness of the negative effects on companies that try to follow the rules. In 1987, the National Academy of Sciences described the "de-Americanization" of world markets: the phenomenon of capitalist countries turning to non-U.S. sources or initiating their own development efforts because of CoCom complications $[49$, p. 12]. The loss to the U.S. economy was estimated at 188,000 jobs and $\$ 17$ billion, considering lost sales to CoCom countries that found the application process cumbersome, potential sales to communist countries, loss of licenses and reduced research and development effort (p. 264). Coupled with the revelations of the loss of strategic technology that would impact military preparedness, these losses suggested that CoCom was harming U.S. companies, not the Soviet Union. 


\section{Ending CoCom in the Age of the Dot-Com Boom}

CoCom was disbanded with the end of the cold war, suggesting that it had completed its task. Although this would seem to indicate that it had fulfilled its mission, the discussion about ending the program failed to incorporate lessons about technology and society. The rationale for ending the organization was just as rooted in determinism as had been the rationale for continuing it. News reports in the period 1991 to 1994 cast the embargo as a mission accomplished, even though the original design of CoCom was unconcerned with technology in general or computers specifically. The notion that computers and telecommunications would uniformly and inevitably transform societies lay behind the release of industries from the proscriptions, though, showing the birth of a new determinism.

\subsection{Connecting Eastern Europe to Information Networks}

The way the interpretation of CoCom could have inhibited the computing community was illustrated by the University of Michigan case, but also in the way connections to Eastern European countries were limited. The leaders of the European Academic Research Network (EARN) had made efforts to connect eastern countries to its network starting in 1987 in order to maintain connections with colleagues, but it was not until March 1990 that the connections were permitted.

The president of EARN described the situation in terms of the interpretation of CoCom offered by the 1983 implementation of the 1979 law. The purchase of a supercomputer, most of which came from the U.S., first required a so-called supercomputer safeguard plan (SSP) that stipulated the equipment could not be used by people in CoCom proscribed countries nor could it have a "direct tie" to their networks. This was a bit perplexing in 1987, when there were many connections that did not give users direct access to the internal mechanisms of a computer, but it also raised the question about computers operating within the U.S. that were sold without SSPs: why could they not connect to eastern Europe?

The management of EARN met with the U.S. Department of Commerce to try resolve these issues in March 1989. EARN learned that there were two concerns. First, it was assumed that connecting a supercomputer to a CoCom country was tantamount to giving them a computer. Second, embargoed software and data could potentially be transmitted. After discussion, Commerce was willing to allow modification of the SSPs. The political changes at the end of 1989 served as an impetus, and the new stipulations were that the users must be made aware of the export rules, links should be limited to $64 \mathrm{kbps}$, electronic mail could be made freely but file transfer must be monitored, and traffic logs must be made. With this agreement, Bulgaria, Czechoslovakia, Hungary, Poland, and the USSR began making preparations to connect to EARN [50]. The choice of these countries was not random: they were the five countries that had developed industrial and educational backgrounds needed in spite of CoCom.

EARN was not the only mechanism to sponsor connections. Hungary's plans for a national network date back to the mid 1980s, and by 1989 a UUCP (USENET) connection was established to other countries while EARN and Internet connections were still 
proscribed [51]. However, this connection could not transform the academic environment immediately. One researcher noted that the "technique of collaboration" would require some adjustment in Hungary. The acceptable use policy, for instance, would create a lot of bureaucracy because certifying that "the behavior of our users is perfectly acceptable" could lead to an administrator stating "therefore I should control everything" [51, p. 446]. It was not just the access to the devices - the researchers also needed the support of a collaborative culture implied by USENET.

In 1990, Hungary told the World Bank that its computer science research capability was fifteen years behind the west. They blamed three factors: the lack of funding for travel, the language barrier with the international community, and technological blockade. Mandatory Russian language instruction led dissatisfaction in foreign languages in general, and as a result many Hungarian researchers spoke no international languages. Researchers were prohibited from connecting to colleagues in capitalist countries via email and the official Soviet sources of information were expensive and slow. A visitor in 1991 noted that telephone system was inadequate; there were fewer than 1 line per 100 people and the quality of the connections were so poor that data could not always be transmitted. Researchers claimed that CoCom had not affected their field, other than sometimes instituting delays in obtaining material [52]. Structural issues, as much or more than access to technology, were to blame.

Similar to the developments in the USSR and Hungary, the development of computing has already been reported for Poland, where academic research networks and a rich community of amateur computing enthusiasts grew in spite of CoCom restrictions [53].

\subsection{Post-Cold War Reevaluation}

Despite political rhetoric praising CoCom, contemporary scholars preferred to blame the culture of the USSR rather than the economic embargo for Soviet difficulties in developing new technology. Igor Artemiev [54] argued at length in 1991 that technology transfer to communist countries is different than in capitalist companies. In a communist system, research is funded by the state and technological innovation does not become private property. Instead, all benefits from an innovation are immediately made the property of the collective. Thus, if a company creates an innovation, there is little compensation. Innovators are required to disseminate their new idea and are only compensated for the reproduction of materials and travel expenses to do so.

The official line in the USSR was that all innovation was shared, but this does not tell the entire story. According to the 1949 Sofia principles, technology would be spread among cooperating countries. For thirty years, the USSR sent out 35,000 sets of documentation and received 17,000 from CMEA countries, supposedly saving members $\$ 20$ billion for technology they would have had to purchase on the open market. Artemiev counters, "One has reason to doubt the meaningfulness of such estimates, when technology transfer is equated with mere copying and mailing of information. Technology transfer can be reduced to information dissemination only when both partners are 
equally developed and possess strong capabilities for the quick and effective transformation of information into productive technology" (p. 82). ${ }^{5}$ This assessment helps to mount a counterargument the CoCom policy even if it does not represent a true success.

After the invasion of Afghanistan and martial law in Poland, Artemiev writes, it was clear that the CMEA was economically vulnerable. A new plan, the Comprehensive Program of Scientific and Technological Progress, was devised to accelerate the development of new technology and effect cooperation among member countries. This program only resulted in $25 \%$ of new technology being shared, while most needs were being met from imports from capitalist countries. This program also failed to help entrepreneurs and research institutions interact, and in fact such a vital function was discouraged. Communist states assign suppliers to consumers, making sure that industrial goods can be assembled into products. "In such an environment, there is no room for joint projects or joint ventures initiated from below" [54, p. 86]. According to Ishii, the effectiveness of trade sanctions "cannot be determined," especially the China trade embargo, but "confusion" is observed among Allies and within Washington [17, p. 30]. In other words, the failure of cooperation among the members of the group makes it difficult to assess whether or not the program was effective.

\subsection{Closing CoCom: A New Determinism}

The Warsaw Treaty Organization disbanded in 1989, and in the same year the Berlin Wall came down, making CoCom's days numbered. In 1990, CoCom announced that about half of the restrictions would be lifted on exports of computers, telecommunications and machine tools to Czechoslovakia, Hungary, and Poland, but nevertheless they would not have as favorable treatment because of the concern that they could forward the material to Russia. The three countries had requested this change and asserted that they could monitor the equipment and make sure it was not put to military use. The favorable arrangement was not as good as China's, though [35].

In its final days, one can see how the assumptions about what CoCom was had clearly changed. One journalist pondering the fate of CoCom in the era of glasnost characterized it this way:

Currently, the 17-member Coordination Committee for Multilateral Controls (COCOM) restricts trade in three broad areas: military hardware, nuclear technology, and industrial or "dual-use" equipment, such as electronic components and advanced optics that have both commercial and military applications....

NATO military strategists have long thought of the Western technological edge as a "force multiplier" which mitigated the numerical advantage enjoyed by Warsaw Pact armies. [55, p. 21]

In 1990, then, it can be said that the attitude toward CoCom was that it was developed to compensate for the lower number of troops in North Atlantic Treaty Organization (NATO) countries as compared to the Warsaw Pact. CoCom's origin, of course, had been related to the export of metals, fuels, and foods - raw materials that could support technological innovation, but not the devices themselves. The new definition

\footnotetext{
${ }^{5}$ In this volume, Sikora, "Cooperating with Moscow," details Comecon transfers in more detail.
} 
of military hardware, nuclear technology, and industrial equipment was more in line with the Reagan administration's export list than anything that had been "long thought of" as the "Western technological edge." This definition was much more recent, and with respect to computers, it was less than ten years old.

This attitude is also seen in the debate over the Export Administration Act reauthorization in 1990, which ultimately eliminated restrictions on all telecommunication equipment. European CoCom countries had argued that "democratic institutions require access to the tools of information gathering and dissemination. Without them, a free press, a responsive government, and an informed electorate are impossible" [56]. The Bush administration had argued that allowing fiber-optic cable to be exported to communist countries would lead to difficulties to monitor communication and that satellite and microwave communication were easier to intercept. The Europeans, for their part, were successful in arguing that CoCom was not designed to facilitate intelligence gathering but to prevent technology transfer to communist military forces.

The new guidelines in 1990 were revisited in 1991, with the result that many personal computers, commercial mainframes, peripheral equipment, and software could be exported without a license [57]. In 1993, during the Clinton administration, it was noted that Israel and Taiwan benefitted from CoCom restrictions because they were not restricted from doing business with Russia, China, and Eastern Europe, even for equipment that intended for civilians. The market for fiber-optic cable and switching equipment was "a potential gold mine": China was expected to spend $\$ 30$ billion and Russia $\$ 15$ billion to update telephone networks [58, p. D3]. Companies like AT\&T and Sun Microsystems in the United States, Northern Telecom of Canada, Alcatel of France, and Siemens of Germany were impacted.

On 31 March 1994, the Clinton Administration announced the end of licensing requirements for much technology that might aid communist countries, including China and the members of the former Soviet Union. The decision was made in order to open what was estimated to be a $\$ 150$ billion market over the following 10 years and lead to the creation of thousands of jobs [59]. The installation of the data networks that would support advanced communication, such as the Internet, represented in a break in the cold war policy. Al Gore's dream of an "information superhighway," which would later lead him to misspeak and claim to have invented the Internet, bled over into foreign policy. One form of determinism had morphed into another.

In the previous year, Clinton administration had proposed raising the limit from 250 million theoretical operations per second (MTOPs) to 500 MTOPs. The administration had received 25,000 applications for export licenses and with the new allowances the number would be cut in half (as noted above, the 1978 total had been 1,680, 62.5 percent of which had been for computers). Basic computer designs from Apple or IBM were limited for export. In 1994, the United States removed licensing requirements for civilian telecommunications equipment and computers that operate up to 1,000 million theoretical operations per second (MTOPs) to former communist countries. The Clinton administration had defined supercomputers as operating above 1,500 MTOPs [59].

CoCom was disbanded in March 1994. Its successor is the Wassenaar Arrangement on Export Controls for Conventional Arms and Dual-Use Goods, which was agreed on 
at the end of 1996. The experience of failed technology transfer that challenged ideologies based on determinism was not much discussed; indeed, the 1979 paradigm about preventing technology transfer still guides U.S. policy.

\section{Conclusion}

In spite of the fact that technological embargos seem to be tested and tried mechanisms today, the story of CoCom shows it was not necessarily the best and only way to achieve policy aims. Although politically popular, the failure of CoCom in terms of technology theory was evident nearly from the beginning. ${ }^{6}$ The various permutations of CoCom, not to mention the high-profile failures, call into question whether the policy could ever have been effective aside from its use as political symbolism. The Soviet success in the atom bomb and Sputnik certainly showed that the earliest version of CoCom was not successful. As well, the contrasting policies of the Reagan and Clinton administrations in the last years of CoCom show how the policy was rooted more in political ideology than it was in a sound theory of technological innovation.

The story of CoCom answers certain mysteries about the history of computing, like why the management of the DNS system became a responsibility of the Department of Commerce - and may perhaps suggest why one of the first top-level domains was dotcom. Some might say that CoCom was effective in delaying the deployment of the Internet into the USSR, arguing that reverse engineering and working from published knowledge was not successful. Yet, Abbate [60] has amply demonstrated how the early culture of the ARPAnet, where research teams at different universities attempted to come together to create a network of peers, was tied to the flexible solution that took hold. This flexibility was necessary for the development of the network. The desire for a "cybernetic society" and a hierarchical reporting structure was more important for computing in the USSR, leading to what Gerovitch [61] has termed the "InterNyet." The lack of development in areas of computing that would lead a western examiner to say that the East Bloc was successful in computing has more to do with the aims and goals of the region than it does with the effectiveness of the embargo.?

The evidence provided by the history of computing has provided support the expectations of the situation based on the social construction of technology. A policy that suggests that a technological device landing on foreign soil will take root and unequivocally transform the economics of the receiving country, after all, is a policy based on technological determinism. From the perspective of social constructivism, one would suggest that the foreign device would have to find a place within the technological environment before it would succeed. Furthermore, devices that are designed to support one type of user environment cannot be facilely transferred to a different milieu. If anything has been convincingly shown by social constructivism, it is that users matter - and the concept of the user precedes the design of a particular device. This should

6 In this volume, Sikora, "Cooperating with Moscow," suggests that there were in fact increased costs in technology due to CoCom, suggesting that the impact was more than symbolic.

7 The development of the OB telemonitor shows that in the 1980s, Soviet computer science was at least the level of the west's: see Kitov, "Main Teleprocessing Monitors," this volume. 
have led to the conclusion that the embargo of technology would largely fail in the effect it purported to achieve.

This is not to say that CoCom had no effect, however. It was certainly effective in the way it segregated the technical communities on either side of the Iron Curtain. It is impossible to say what could have happened had the sides been in closer communication, but if innovation depends on the international scientific community, then conceivably the damage to the international community that supports innovation harms both sides. The ignominy and even punishment meted upon those who sought to encourage cooperation under the Iron Curtain had a chilling effect on the international community instead of mobilizing that community to be cultural ambassadors, which could have been a more effective deterrent to hostilities.

\section{References}

1. Cupitt, Richard T. and Suzette R. Grillot. COCOM is dead, long live COCOM: persistence and change in multilateral security institutions. British Journal of Political Science. Vol. 27, Iss. 3 (July 1997): pp 361-389.

2. Wendt, Alexander. Social Theory of International Politics. New York: Cambridge UP, 1999.

3. Baldwin, David Allen. Economic Statecraft. Princeton University Press, 1985.

4. Harris, Jennifer M. and Robert Blackwill. War by Other Means: Geoeconomics and Statecraft. Harvard University Press, 2016.

5. Wittfogel. Karl A. Oriental Despotism: A Comparative Study of Total Power. New Haven: Yale University Press, 1957.

6. Mumford, Lewis. "Authoritarian and Democratic Technics." Technology and Culture 5.1 (1964): 1-8.

7. Ellul, Jacques. The Technological Society (1954, trans. 1964). Trans. John Wilkinson. New York: Knopf, 1970.

8. Winner, Langdon. Autonomous Technology: Technics-out-of-Control as a Theme in Political Thought. MIT Press, 1977.

9. Pacey, Arnold. Technology in World Civilization. Cambridge: MIT Press, 1990.

10. Jakhu, Ram and Joseph Wilson. The New United States Export Control Regime: Its Impact on the Communications Satellite Industry. Annals of Air and Space Law Vol. 25. (2000): $157-181$.

11. Cain, Frank. "Computers and the Cold War: United States Restrictions on the Export of Computers to the Soviet Union and Communist China." Journal of Contemporary History 40.1 (2005): 131-147.

12. Libbey, James K. "CoCom, Comecon, and the Economic Cold War." Russian History 37 (2010): 133-152.

13. Yasuhara, Yoko. "The Myth of Free Trade: The Origins of COCOM 1945-1950." The Japanese Journal of American Studies 4 (1991): 127-148.

14. Mastanduno, Michael. Economic Containment: CoCom and the Politics of East-West Trade. Ithaca: Cornell UP, 1992.

15. Adler-Karlsson, Gunnar. Western Economic Warfare 1947-1967: A Case Study in Foreign Economic Policy. Stockholm: Almqvist\&Wiksell, 1968

16. Bertsch, Gary K. East-West Strategic Trade, COCOM and the Atlantic Alliance. Paris: Atlantic Institute for International Affairs, 1983

17. Ishii, Osamu. China trade embargo and America's alliance management in the 1950s: the Japanese case. Hitotsubashi Journal of Law and Politics 20 (February 1992): pp. 23-31. 
18. Campbell-Kelly, Martin and William Aspray. Computer: A History of the Information Machine NY: Basic, 1996.

19. Corson, Dale R. Scientific Communication and National Security: A Report Prepared by the Panel on Scientific Communication and National Security Committee on Science, Engineering, and Public Policy. Washington, D.C.: National Academy Press, 1982.

20. Goodman, S. E. "Technology Transfer and the Development of the Soviet Computer Industry." In Trade, Technology, and Soviet-American Relations. Bloomington: Indiana University Press, 1985: pp 117-140.

21. Brand, Stewart. "Founding Father." Wired 9.03 (1 March 2001).

22. Kemme, David M., ed. Technology Markets and Export Controls in the 1990s. NYU Press, 1991.

23. Leitner, Peter M. Decontrolling Strategic Technology, 1990-1992: Creating the Military Threats of the 21st Century. New York: University Press of America, 1995.

24. Peters, Benjamin. How Not to Network a Nation: The Uneasy History of the Soviet Internet. MIT Press, 2016.

25. Bucy, Fred. An Analysis of Export Control of U.S. Technology - a DOD Perspective: A Report of the Defense Science Board Task Force on Export of U.S. Technology. Washington, DC: Office of the Director of Defense Research and Engineering, 1976.

26. Kemme, David M., ed. Technology Markets and Export Controls in the 1990s. NYU Press, 1991.

27. Donovan, Christopher J. “The Export Administration Act of 1979: Refining United States Export Control Machinery, Boston College International and Comparative Law Review 4.1 (1981): pp. 77-114.

28. Freedenberg, Paul. “The Commercial Perspective.” Export Controls in Transition: Perspectives, Problems, and Prospects. Gary K. Bertsch and Steven Elliot-Grower, eds. Durham: Duke UP, 1992: pp. 27-58.

29. Yuan, Jing-dong. "The Politics of the Strategic Triangle: the U.S., COCOM, and Export Controls on China, 1979-1989. "Journal of Northeast Asian Studies (Spring 1995): pp. 4779.

30. Holstein, William J. "Burroughs Corp. announced Wednesday it has contracted to sell..." UPI Archive: Financial, 4 Nov. 1981. Infotrac Newsstand, http://link.galegroup.com/. Accessed 13 June 2018.

31. Burns, John F. "China's Passion for the Computer.” New York Times, 6 Jan. 1985.

32. "Allies meet on sanctions against Moscow." UPI Archive: International, 19 Jan. 1982. Infotrac Newsstand, http://link.galegroup.com/. Accessed 13 June 2018.

33. Weinberger, Caspar. "Annual Report to Congress." 8 February 1982. https://apps.dtic.mil/dtic/tr/fulltext/u2/a113991.pdf

34. Gelb, Leslie H. Weinberger Says Soviet Weapons Are Aided by Western Technology. New York Times 22 May 1982, p. 5.

35. Phillips, John (1990). “Cocom to Ease Restrictions on Eastern Europe.” UPI Archive: International, 16 Feb. 1990. Infotrac Newsstand, http://link.galegroup.com/ Accessed 13 June 2018.

36. Jentleson, Bruce W. and Jane Haaland Matlary. "Soviet-Western Energy Trade: From Trade Controls to Energy Interdependence?" Export Controls in Transition: Perspectives, Problems, and Prospects. Gary K. Bertsch and Steven Elliot-Grower, eds. Durham: Duke UP, 1992: pp 203-231.

37. "The United States and its European allies reached unanimous..." UPI Archive: International, 20 Jan. 1982. Infotrac Newsstand, http://link.galegroup.com/. Accessed 13 June 2018. 
38. "France signed a 25-year agreement today with the Soviet..." UPI Archive: International, 23 Jan. 1982. Infotrac Newsstand, http://link.galegroup.com/. Accessed 13 June 2018.

39. Beardsley, Tim. COCOM Agreement on Computers." Nature 310 (2 August 1984), p. 355.

40. Wilkins, Bryan. U.S., Allies Restrict Technological Exports to Eastern Bloc. Computerworld 30 July 1984, p. 16.

41. Leslie, Christopher. "Flame Wars on Worldnet: Early Constructions of the International User." International Histories of Invention and Innovation: IFIP Advances in Information and Communication Technology, Vol. 491: pp. 122-140.

42. Buchan, David. Technology transfer to the soviet bloc. The Washington Quarterly, 7:4 (1984), pp. 130-135.

43. Schonfeld, Zach. "'KREMVAX': The Strange Story of the Internet's First April Fools' Prank.” Newsweek 1 April 2015, www.newsweek.com, accessed 23 June 2018.

44. Werner, Leslie Maitland. "U.S. Has Bonn Stop Soviet-Bound Computer." New York Times 15 November 1983: A1.

45. "Swedes Sieze [sic] 2d Shipment of Equipment." New York Times 25 November 1983: A3.

46. Crawford, Beverly. "Changing Export Controls in an Interdependent World: Lessons from the Toshiba Case for the 1990s" (pp. 249-290). Export Controls in Transition: Perspectives, Problems, and Prospects. Gary K. Bertsch and Steven Elliot-Grower, eds. Durham: Duke UP, 1992.

47. Greenhouse, Steven. French Linked to Soviet Sale. New York Times 17 October 1987.

48. Sanger, David. New Hints that East Bloc Got Japanese Equipment.” New York Times (30 July 1989).

49. Allen, Lew, et al. Balancing the National Interest: U.S. National Security Export Controls and Global Economic Competition. National Academy Press, 1987.

50. Greisen, Frode. EARN Connections to East Europe and Regulatory Issues. North-Holland Computer Networks and ISDN Systems 19 (1990): pp. 177-180.

51. Turchanyi, Geza. "Networking in Hungary." Computer Networks and ISDN Systems 25 (1992): pp. 444-447.

52. Peck, Shirley S. "Research in Post-Communist Hungary." Information Development 8.4 (November 1992): pp. 204-209.

53. Leslie, Christopher and Patrick Gryczka. "Ingenuity in Isolation: Poland in the International History of the Internet," Proceedings of the 11th International Federation of Information Processing's Technical Committee 9 conference on Human Choice and Computers, ed. Kai Kimppa et al., pp. 162-75.

54. Artemiev, Igor E. "Global Technology Markets and Security Issues" (73-103). Technology Markets and Export Controls in the 1990s. David M. Kemme, ed. NYU Press, 1991.

55. Hamilton, David P. Will glasnost wash over U.S. export controls? Science 248.4951 (Apr. 6, 1990): p. 21 .

56. Freedenberg, Paul. COCOM in a period of change (MITJP 90-06). Cambridge: The MIT Japan Program, 1992.

57. IDG News Service, "New COCOM rules ease net exports." Network World (12 August 1991): pp. 29, 32.

58. Ramirez, Anthony. "Move Gains to Liberalize U.S. High-Tech Exports." New York Times, 21 September 1993, p. 3.

59. Friedman, Thomas L. U.S. ending curbs on high-tech gear to cold war foes. New York Times, 31 March 1994, p. 1.

60. Abbate, Janet. Inventing the Internet. MIT Press, 2000.

61. Gerovich, Slava. InterNyet: Why the Soviet Union did not build a nationwide computer network. History and Technology, Vol. 24, No. 4 (December 2008): 335-350. 